\title{
Retraction Note to: Fibroblast growth factor receptor 4 polymorphisms and the prognosis of non-Hodgkin lymphoma
}

\author{
${\text { Zhanshan } \mathrm{Cha}^{1} \cdot \text { Yan Zang }^{1} \cdot \text { Huijun Guo }}^{1} \cdot$ Haihui Gu ${ }^{1} \cdot$ Xiaohua $\mathrm{Tu}^{1}$. \\ Haihan Song ${ }^{1} \cdot$ Baohua Qian ${ }^{1}$
}

Published online: 6 June 2016

(C) Springer Science+Business Media Dordrecht 2016

\section{Retraction Note to: Mol Biol Rep (2014) 41(2):1165-1170 DOI 10.1007/s11033-013-2963-y}

The Editor-in-Chief of Molecular Biology Reports retracts the above-mentioned article per the Committee on Publication Ethics guidelines on plagiarism and related questionable writing practices. The article uses as a template substantial portions of text of which a large part have been paraphrased in order to describe another association of FGFR4 polymorphisms with a disease (NHL versus CAD) from the following source(s):

Lan Ma, Haifeng Zhang, Carrie Han, Danian Tong, Meiyan Zhang, Yi'an Yao, Yu Luo, and Xuebo Liu, Fibroblast growth factor receptor 4 polymorphisms and susceptibility to coronary artery disease, DNA and Cell Biology. June 2012, 31(6): 1064-1069. doi:10.1089/dna. 2011.1552.
Qing Zhu, Tongtao Liu, Fibroblast growth factor receptor 4 polymorphisms and coronary artery disease: a case control study, Molecular Biology Reports, June 2012, 39(9): 8679-8685. doi:10.1007/s11033-012-1723-8.

HF Zhang, KJ Zhao, PF Yang, YB Fang, YH Zhang, JM Liu and QH Huang, Association between fibroblast growth factor receptor 4 Gly388Arg polymorphism and ischaemic stroke, The Journal of International Medical Research, October 2012, 40(5): 1708-1714. doi:10.1177/030006051204000509.

Chen H, Tong J, Zou T, Shi H, Liu J, Du X, Yang J, Ma $\mathrm{C}$, Fibroblast growth factor receptor 4 polymorphisms are associated with coronary artery disease. Genet Test Mol Biomarkers, 16:952-956, 2012.

In addition, further investigation showed irregularities in the peer review process leading us to believe that the peer review process was compromised.
The online version of the original article can be found under doi:10.1007/s11033-013-2963-y.

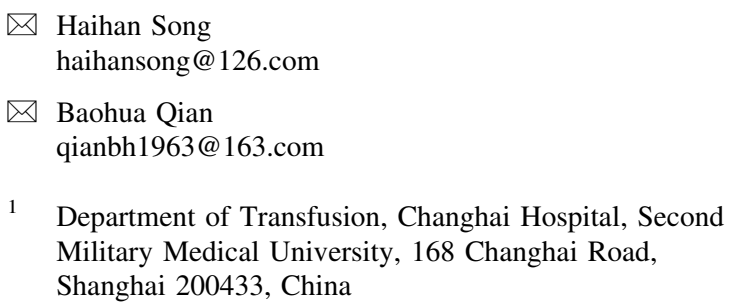

2 Department of Internal Medicine, Emergency Center, Shanghai East Hospital, Tongji University, 150 Jimo Road, Shanghai 200120, China 